\title{
Drilling the Eger Rift in Central Europe
}

\section{by Aleš Špičák, Andrea Förster, and Brian Horsfield}

An ICDP international workshop "Drilling the Eger Rift," was held at the estate Býkov, about $100 \mathrm{~km}$ west of Prague, Czech Republic, on 3-7 October, 2004. It was organized by the Geophysical Institute of the Academy of Sciences of the Czech Republic and the Czech Geological Survey and financially supported by the ICDP.

The workshop was aimed at discussing the scientific goals that would justify deep drilling in the western part of the Eger Rift area (Fig. 1). The Eger Rift, located in the northwestern part of the Bohemian Massif, is a key site that has attracted the international geoscience community for many decades. The rift is the result of young, deep-seated geodynamic processes manifested by episodic Cenozoic volcanism (the youngest at $0.2-0.5 \mathrm{Ma}$ ), repeated earthquake swarms, numerous mineral springs, $\mathrm{CO}_{2}$ emissions with high ${ }^{3} \mathrm{He}$ content, and abundant mofettes. The crustmantle boundary $(27 \mathrm{~km})$ and lithosphere-asthenosphere boundary $(80-90 \mathrm{~km})$ are shallow compared to the conditions below the Bohemian Massif. Also, surface heat flow $\left(60-80 \mathrm{~mW} \mathrm{~m}^{-2}\right)$ within the rift zone is higher than within the massif.

Owing to the diversity of available data stretching over various fields of geoscience, the area is an ideal place to foster studies on the interaction between active mantle, crust, and deep biosphere processes. The workshop thus formed a platform on which the state of the art in investigating the rift was summarized and new research targets addressed by drilling were defined.

According to the interacting research fields, the workshop was streamed into six topical blocks. The first block focused on geology, tectonics, and fluids covering the tectono-sedimentary evolution of the Eger Rift and Cenozoic alkaline volcanic series, as well as meteoric, magmatic, and fossil components of deep fluids. The session "Evolution of the Lithosphere" stressed the receiver function studies from the recent international BOHEMA passive seismic experiment, the analyses of lower crustal and mantle xenoliths, and the necessity to investigate the geothermal and rheological conditions of the lithosphere. Contributions in the session on "Earthquake Swarm Processes" dealt both with space-time distribution of swarm earthquakes and related geophysical and geochemical parameters ,and with models of earthquake swarms. Within the block "FluidRelated Seismic Processes", such processes were not only analyzed in general, but also the results from two ICDP projects were presented: German Continental Deep Drilling Programm (KTB) and Long Valley Caldera, Calif., U.S.A. The "Deep Biosphere" session thoroughly introduced this interdisciplinary field of science and its dependency on deep drilling and provided two examples of such studies from mineral springs of Bad Brambach (Germany). A session on issues of "Drilling and Borehole Monitoring" covered the technical aspects of drilling, the possibilities of multi-parameter continuous monitoring, and how a deep borehole could be turned to a multi-sensor laboratory.

The workshop concluded that the two manifestations of anomalous mantle-crust interaction (the occurrence of earthquake swarms at shallow depth and the occurrence of $\mathrm{CO}_{2}$ - and ${ }^{3} \mathrm{He}$-rich fluids) are worth investigating by deep drilling and by an extensive monitoring program. The research conducted hitherto into earthquake swarms in the Eger Rift (Fig. 2) focuses on the role of fluids in this process. Thus, one principal scientific objective of drilling the Eger Rift is to improve the understanding of triggering mechanisms that generate swarm-earthquake activity. In most cases, fluid-triggered earthquakes are generated through fluid-injection from the surface. A deep drill hole in the Eger Rift would allow investigating fluid-injection-triggered seismicity from either 
direction (naturally upward migrating fluids and man-made hydraulic tests) at the same time, which would clearly be a worldwide unique experiment. Furthermore, applying state-of-the-art seismic monitoring techniques would allow performing stress field determinations that could be related to in situ stress field measurements. Such investigations extend the activities addressed by the San Andreas Fault Zone Observatory at Depth (SAFOD) project at Parkfield, Calif., U.S.A., where earthquake triggering is investigated in a completely different tectonic environment at one of the largest transform faults. Besides research on triggered earthquakes, a 6-7-km-deep borehole in western Bohemia would provide a unique possibility to monitor and study the behavior of rocks and fluids from the surface down to the source region of earthquake swarms. Even more intriguing, and what makes the Eger Rift unique as far as ICDP sites are concerned, is the triggering of deep microbial activity by fluid release during the earthquake swarms. Methane is generated as part of this activity, attesting to a coupling of the biosphere and geosphere. Drilling the Eger Rift would provide an exciting opportunity to sample and monitor this fascinating phenomenon.

Mineral springs are important for the continued prosperity of the surrounding areas (e.g., in Karlovy Vary). The results from the borehole laboratory would help us to understand better the mechanisms driving the spas, for instance, whether the deep fluid circulation is related to shallow fluids feeding the springs in the spas. This is clearly of great socio-environmental relevance.

At the end of the workshop, a field trip introduced the participants to key sites in western Bohemia including the thermal springs at Karlovy Vary Spa, the potential drilling site in the northern part of the Cheb sedimentary basin (in the vicinity of the seismically dominant Nový Kostel earthquake focal zone), the Bublák mofette (surrounded by seismic stations of the WEBNET (Academy of Sciences, Prague) and KRASNET (Brno University) networks), the $\mathrm{CO}_{2}$ exhalations at Soos, and the Železná Hůrka volcano and its tephra deposits.

\section{Authors}

Aleš Špičák, Geophysical Institute of the Academy of Sciences of the Czech Republic, Bocni II/1401 14131 Prague 4 Czech Republic, e-mail: als@ig.cas.cz

Andrea Förster, GeoForschungsZentrum Potsdam, Telegrafenberg, 14473 Potsdam, Germany

Brian Horsfield, GeoForschungsZentrum Potsdam, Telegrafenberg, 14473 Potsdam, Germany

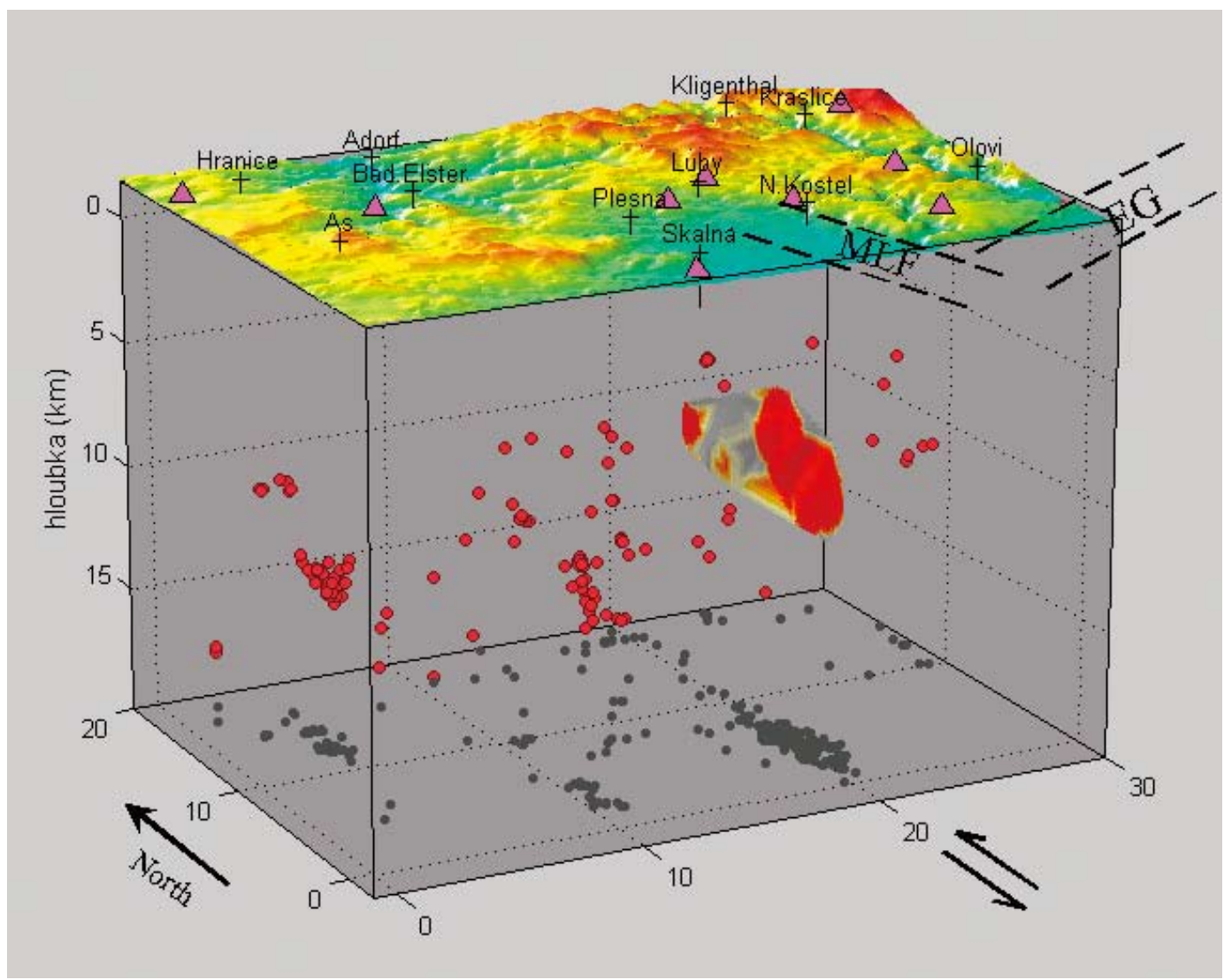

Figure 2. Schematic 3-D section of the Nový Kostel area. The main epicentral cluster indicated by red surface occurs at depths of $6-11 \mathrm{~km}$ below the eastern margin of the Cheb Basin. Triangles indicate seismic stations of WEBNET. EG and MLF denote the main tectonic structures of Eger Rift and Mariánské Lázně Fault. 